\title{
The diagnostic process of covid-19 in the emergency department: laboratory and imaging methods
}

\author{
(D)Fatih Guneysu' \\ iD Yusuf Yurumez ${ }^{2}$ \\ (iD) Ertugrul Guclu³ \\ (iD) Mehmet Koroglu 4 \\ (iD) Alper Karacan 5 \\ Decip Gokhan Guner ${ }^{\mathbf{1}}$ \\ (iD) Yesim Durgun ${ }^{\mathbf{1}}$
}

1. Sakarya University Training and Research Hospital, Clinic of Emergency Medicine, Sakarya, Turkey. 2. Sakarya University Faculty of Medicine, Department of Emergency Medicine, Sakarya, Turkey. 3. Sakarya University Faculty of Medicine, Department of Infectious Diseases and Clinical Microbiology, Sakarya, Turkey. 4. Sakarya University Faculty of Medicine, Department of Clinic Microbiology, Sakarya, Turkey. 5. Sakarya University Faculty of Medicine, Department of Radiology, Sakarya, Turkey.

\section{SUMMARY}

OBJECTIVES: The 2019 Novel coronavirus disease puts a serious burden on the health system. Therefore, the detection of particularly serious patients at an early stage is extremely important in terms of controlling the outbreak and improving the prognosis. We investigated the role of inflammatory markers studied in patients suspected of COVID-19 at an emergency department in predicting PCR and CT results.

METHODS: This retrospective study was carried out with 133 patients who were admitted between 13 March and $7^{\text {st }}$ April 2020 with suspicion of COVID-19. The patients were divided into four groups according to CT and RT-PCR results and evaluated.

RESULTS: Considering all patients, no specific findings were found in the hematological and biochemical values of patients in the laboratory analyses. Although all of the results remained within the reference range, there was a significant difference in white blood cell, neutrophil, platelet, and lymphocyte values when the groups were compared [ $p=0.000 ; p=0.004 ; p=0.022 ; p=0.023$ ].

CONCLUSION: Laboratory is not specific enough in the pre-diagnosis. In addition, this result does not alter with PCR or CT positivity. However, minimal changes observed in laboratory results may be partially guiding in patients in whom both PCR and CT are positive.

KEYWORDS: Coronavirus Infections/diagnosis. Laboratory Test. Diagnostic Imaging. Tomography, X-Ray Computed. Emergency Service, Hospital.

\section{INTRODUCTION}

In early December 2019, the first patient of the 2019 novel coronavirus pneumonia emerged in the city of Wuhan, Hubei province, China'. The disease and the virus that causes it have been named as 2019 Novel coronavirus disease [COVID-19] and SARS-COV-2, respectively ${ }^{2}$. COVID-19 is transmitted by inhalation or contact with infected droplets and its incubation period ranges from 2 to 14 days'. 
Similar to other viral respiratory pathogens, COVID-19 presents in the majority of cases with a rapidly progressive course of fever, cough, and dyspnea ${ }^{3}$. Despite the use of optimal supportive interventions, the fatality rate among hospitalized patients is over $10 \%$.

Important distinguishing factors of the disease are leukopenia and the rapid progression to acute respiratory distress syndrome[ARDS] $]^{5}$. Because of this, it is extremely important to detect the infected person at an early stage and immediately isolate them from the healthy population ${ }^{6}$.

RealTime - Polymerase Chain Reaction [RT-PCR] is recommended to detect positive nucleic acid for SARSCoV-2 in sputum, Oro-Nasopharyngeal Swab [ONS], and secretions of the lower respiratory tract samples for the diagnosis of patients with suspected infection; however, the low sensitivity of RT-PCR implies that many COVID-19 patients may not be identified and receive appropriate treatment in time ${ }^{7}$. Nevertheless, chest computed tomography [CT] is relatively easy to use as a routine imaging tool for the diagnosis of pneumonia and a rapid method 19 to diagnose COVID-196. CT results are generally abnormal, even in those without symptoms ${ }^{8}$. In addition, biomarkers such as white blood cell [WBC], neutrophil [NEU], lymphocyte [LYM], platelet [PLT], neutrophil/lymphocyte ratio [NLR], platelet/lymphocyte ratio [PLR] and C-reactive protein [CRP] have been suggested as useful determinants for the prognosis of patients with viral pneumonia?

In this study, besides demonstrating the success of the laboratory and imaging methods in predicting the disease during the first application, we aimed to evaluate the diagnostic values of PCR and CT.

\section{METHODS}

This retrospective study was carried out among 133 patients who were admitted to the Sakarya University Education and Research Hospital between 13 March and $1^{\text {st }}$ April 2020 with suspicion of COVID-19. The study protocol was approved by the local ethics committee of the Sakarya University School of Medicine [IRB No:71522473/050.01.04/21].

\section{Patients and Study design}

The data required for this retrospective study were obtained from the medical records of the patients in the information system of our hospital. Demographic characteristics, complaints, laboratory results [hematological, biochemical, and serological tests], RT-PCR assay of ONS swab samples, CT, and hospitalization requirements were recorded within the scope of the study.

The inclusion and exclusion criteria for the study are as follows.

- Inclusion criteria: Patients over 18 years old who underwent both chest CT imaging and RT-PCR test with ONS swab samples.

- Exclusion criteria: Patients under 18 years old and whose records could not be found were excluded from the study.

The patients were divided into four groups, based on the criteria described ahead, and examined.

- Group 1 [28 patients]: CT negative and RT-PCR negative;

- Group 2 [53 patients]: CT positive and RT-PCR negative;

- Group 3 [35 patients]: CT negative and RT-PCR positive;

- Group 4 [17 patients]: CT positive and RT-PCR positive.

In the study published by The Republic of Turkey Public Health Institution, patients over 50 were considered to be at high risk ${ }^{10}$. In our study, patients were examined in two groups, under 50 and over 50.

\section{Chest $\mathrm{CT}$ protocol and image analysis}

CT scans performed in the emergency room were included in this study and evaluated by our hospital's radiologists. All images were obtained using a CT system [Toshiba Alexion 16 Multi-Slice, Japan] with patients in the supine position. The radiologists reported the chest CT as COVID-19 positive or negative.

\section{RT-PCR assay protocol}

After the samples were brought to the microbiology laboratory, they were registered in the laboratory operating system, and the ONS sample from the same patient were sequentially analyzed with the same PCR set-up. The isolation of all samples was carried out in a negative-pressure room in a class 2-a biosafety cabinet.

RNA isolation from ONS samples was performed with the EZ1 [Qiagen, Germany] device. Elution of 60 $\mu \mathrm{l}$ of $400 \mu \mathrm{l}$ sample was taken and used as a template in RT-PCR reaction.

For the RT-PCR study, a $10 \mu \mathrm{l}$ master mix, $2 \mu \mathrm{l}$ primer, and $8 \mu \mathrm{l}$ RNA mixture were prepared per sample with genesis RT-PCR SARS-CoV-2 [Primer Design, 
UK] kit. The reaction was carried out with a total reaction volume of $20 \mu \mathrm{l}$ [Table-1].

At the end of the reaction, Cycle Threshold values were used as an approximate indicator of the number of copies of the SARS-CoV-2 RNA. A Cycle Threshold value of less than 45 was interpreted as positive for the SARS-CoV-2 RNA.

\section{Statistical analysis}

The SPSS software version 21.0 was used for statistical analyses. Mean values are specified for continuous variables that match the normal distribution, while median values are specified for continuous variables that do not conform to the normal distribution. Statistical analysis of non-parametric continuous variables used Mann Whitney U and Kruskal Wallis tests, as well as the student t-test and one-way ANOVA in the analysis of parametric continuous variables. Post hoc analyses were conducted according to Tamhane for non-parametric continuous variables that did not conform to the normal distribution, according to Tukey for parametric continuous variables that match the normal distribution. Percentage values are given in the sharing of Nominal Categorical data, and statistical analyzes were made by the $\mathrm{X}^{2}$ test. All tests were done with a two-tailed significance of $5 \%$. For each endpoint, the absolute and relative effects and their corresponding 95\% CIs were calculated as recommended by Altman and colleagues.

\section{RESULTS}

The general characteristics of the 133 patients included in the study are shown in Table 2.78 [58,6\%] of the patients were male. Among these parameters, no specific findings were detected from the hematological and biochemical values of the patients. The CRP median value was found to be high as $16 \mathrm{mg} / \mathrm{dl}$. In contrast, 52 [39,1\%] of the patients had positive RT-PCR results and $88[66,2 \%]$ had pathological findings on CT. Most of the patients admitted to the emergency department were hospitalized and treated [n: 114, $85,7 \%]$.

The relationship between diagnostic parameters and age is shown in Table 3. We found that men are more affected than women, both under and over 50. A decrease in LYM and an increase in CRP values were observed in patients of 50 years, which was statistically significant $[p=0.018, p=0.003]$. There was no relationship between age and PCR results. On the other hand, a significant difference was found in patients under 50 and over 50 in terms of CT findings [ $p=0.002]$. Hospitalization was statistically high in both groups $[\mathrm{p}=0.000]$.

The relationship between diagnostic parameters and gender is shown in Table 4. We observed that PLT and CRP levels were increased with statistical significance in men [respectively; $p=0.024$, $\mathrm{p}=0.016]$. There was no significant difference in terms of hospitalization.

The relationship between laboratory parameters and the groups are shown in Table 5. When the groups were analyzed in terms of WBC, NEU, PLT, and LYM values, a significant difference was found between the groups $[p=0.000 ; p=0.004 ; p=0.022$; $\mathrm{p}=0.023$, respectively]. It is also noteworthy that in Group 4, the median values of WBC, NEU, PLT, and LYM are lower than in the other groups and the CRP median value is higher. In the subgroup analysis, a

TABLE 1. TIME AND TEMPERATURE VALUES OF COVID-19 REAL-TIME PCR ASSAY.

\begin{tabular}{|c|c|c|c|}
\hline \multicolumn{2}{|l|}{ Cycles } & Temperature & Time \\
\hline \multicolumn{2}{|c|}{ Reverse transcription } & $55^{\circ} \mathrm{C}$ & 10 minutes \\
\hline \multicolumn{2}{|c|}{ Enzyme activation } & $95^{\circ} \mathrm{C}$ & 2 minutes \\
\hline \multirow[t]{2}{*}{ X50 cycles } & Denaturation & $95^{\circ} \mathrm{C}$ & 10 seconds \\
\hline & Annealing and extension & $60^{\circ} \mathrm{C}$ & 60 seconds \\
\hline
\end{tabular}

TABLE 2. GENERAL CHARACTERISTICS OF PATIENTS.

\begin{tabular}{|c|c|c|}
\hline & & $n=133$ \\
\hline Age [Years; Mean [SD]] & & $49.50[18.82]$ \\
\hline \multirow[t]{2}{*}{ Gender } & Female [\%] & $55[41.4]$ \\
\hline & Male [\%] & $78[58.6]$ \\
\hline WBC[K/uL $]$ & & $6.80[5.2-8.4]$ \\
\hline Neutrophil [K/uL] & & $4.30[3.0-5.6]$ \\
\hline Platelets [K/uL] & & $196.00[160.00-246.50]$ \\
\hline Lymphocytes [K/uL] & & $1.60[1.10-2.15]$ \\
\hline CRP $[\mathrm{mg} / \mathrm{L}]$ & & $16.00[5.00-46.00]$ \\
\hline NLR & & $2.47[1.71-3.54]$ \\
\hline$P L R$ & & 118.75 [83.86-162.67] \\
\hline \multirow[t]{2}{*}{ PCR } & Positive [\%] & $52[39.1]$ \\
\hline & Negative [\%] & 81 [60.9] \\
\hline \multirow[t]{2}{*}{ CT } & Positive [\%] & 88 [66.2] \\
\hline & Negative [\%] & $45[33.8]$ \\
\hline \multirow[t]{2}{*}{ Hospitalization } & Discharge [\%] & 19 [14.3] \\
\hline & Hospitalize [\%] & 114 [85.7] \\
\hline
\end{tabular}

Data are number [\%] or a median, unless otherwise indicated. ${ }^{*}$ The median values [25p-75p] were indicated because parameters did not fit the normal distribution.

WBC: White Blood Cell; CRP: C-Reaktive Protein; NLR: Neutrophil-Lymphocyte ratio; PLR: Platelet-Lymphocyte Ratio; PCR: Polymerase Chain Reaction; CT: Computed Tomography. 
statistically significant difference in WBC values was found between Group 1 and Group 4 and between Group 2 and Group 4 [p=0.017; $\mathrm{p}=0.005$, respectively]. When subgroup analysis was made in terms of NEU values, there was a statistically significant difference between Group 2 and Group 4 [p=0.004]. In the subgroup analysis of PLT values, a significant difference was found only between Group 3 and Group 4 [p=0.037]. When the median values of
CRP were analyzed, they were found to be higher in Group 2 and Group 4 in patients with positive CT findings [Group 2, $19 \mathrm{mg} / \mathrm{dl}$; Group 4, $18 \mathrm{mg} / \mathrm{dl}$ ]. When evaluated in terms of Group 4, an increase in CRP and a decrease in other laboratory parameters were observed. The lowest median value in terms of CRP was seen in Group 3[5 mg/dl]. Despite all these results, we observed that all test values remained within the reference range.

TABLE 3. COMPARISON OF THE LABORATORY PARAMETERS, CT, PCR, AND HOSPITALIZATION BETWEEN PATIENTS UNDER 50 AND OVER 50 YEARS OLD.

\begin{tabular}{|c|c|c|c|c|}
\hline & & Age $<50[$ min-max $]$ & Age $\geq 50[$ min-max $]$ & $\mathrm{p}$ \\
\hline \multirow[t]{2}{*}{ Gender } & Male n [\%] & $42[31.6]$ & $36[27.1]$ & \multirow[t]{2}{*}{0.292} \\
\hline & Female $\mathrm{n}[\%]$ & 27 [20.3] & 28 [21.1] & \\
\hline WBC [K/uL] & & $7.09[5.30-8.30]$ & 6.65 [5.10-9.13] & 0.864 \\
\hline Neutrophil [K/uL] & & $4.40[3.00-5.50]$ & $4.20[2.96-6.58]$ & 0.617 \\
\hline Platelets [K/uL] & & $196.00[163.50-243.50]$ & 195.00 [149.25-265.75] & 0.836 \\
\hline Lymphocytes [K/uL] & & $1.70[1.30-2.40]$ & $1.50[1.02-2.00]$ & 0.018 \\
\hline CRP $[\mathrm{mg} / \mathrm{L}]$ & & 10.00 [2.70-34.00] & 19.50 [7.25-50.75] & 0.003 \\
\hline NLR & & 2.30 [1.56-3.48] & $2.70[1.78-4.87]$ & 0.617 \\
\hline PLR & & 118.75 [84.17-146.05] & 117.20 [82.24-206.79] & 0.836 \\
\hline \multirow[t]{2}{*}{ CT } & Positive n [\%] & $37[27.8]$ & 51 [38.3] & \multirow[t]{2}{*}{0.002} \\
\hline & Negative n [\%] & 32 [24.1] & 13 [9.8] & \\
\hline \multirow[t]{2}{*}{ PCR } & Positive n [\%] & 29 [21.8] & $23[17.3]$ & \multirow[t]{2}{*}{0.517} \\
\hline & Negative n [\%] & $40[30.1]$ & $41[30.8]$ & \\
\hline \multirow[t]{2}{*}{ Hospitalization } & Discharge n [\%] & 17 [12.8] & $2[1.5]$ & \multirow[t]{2}{*}{0.000} \\
\hline & Hospitalize n [\%] & 52 [39.1] & $62[46.6]$ & \\
\hline
\end{tabular}

Data shown are number [\%] or a median, unless otherwise indicated. ${ }^{\star}$ The median values [25p-75p] were indicated because parameters did not fit the normal distribution. WBC: White Blood Cell; CRP: C-Reaktive Protein; NLR: Neutrophil-Lymphocyte ratio; PLR: Platelet-Lymphocyte Ratio; PCR: Polymerase Chain Reaction; CT: Computed Tomography

TABLE 4. COMPARISON OF THE LABORATORY PARAMETERS, CT, PCR, AND HOSPITALIZATION BETWEEN MALE AND FEMALE PATIENTS.

\begin{tabular}{|c|c|c|c|c|}
\hline & & Male[min-max] & Female[min-max] & $\mathrm{p}$ \\
\hline Age [Years] & & $50.29[18.50]$ & $48.05[17.24]$ & 0.481 \\
\hline WBC $[K / u L]$ & & $7.10[5.25-8.85]$ & $6.60[5.10-8.10]$ & 0.317 \\
\hline Neutrophil [K/uL] & & $4.50[3.19-6.20]$ & $4.00[2.70-5.30]$ & 0.165 \\
\hline Platelets [K/uL] & & $185.00[160.75-226.50]$ & 212.00 [158.00-277.00] & 0.024 \\
\hline Lymphocytes [K/uL] & & $1.50[1.10-2.10]$ & $1.70[1.10-2.30]$ & 0.257 \\
\hline $\mathrm{CRP}[\mathrm{mg} / \mathrm{L}]$ & & $21.00[6.38-59.75]$ & $8.00[3.00-24.00]$ & 0.016 \\
\hline NLR & & $2.79[1.95-4.23]$ & $2.25[164-3.22]$ & 0.062 \\
\hline PLR & & $118.61[82.65-154.86]$ & 120.56 [84.38-167.33] & 0.569 \\
\hline \multirow[t]{2}{*}{$P C R$} & Positive n [\%] & $31[23.3]$ & $21[15.8]$ & \multirow[t]{2}{*}{0.856} \\
\hline & Negative n [\%] & $47[35.3]$ & $34[25.6]$ & \\
\hline \multirow[t]{2}{*}{$\mathrm{CT}$} & Positive n [\%] & $52[39.1]$ & $36[27.1]$ & \multirow[t]{2}{*}{0.884} \\
\hline & Negative $\mathrm{n}[\%]$ & $26[19.5]$ & 19 [14.3] & \\
\hline \multirow[t]{2}{*}{ Hospitalization } & Discharge $n[\%]$ & $11[8.3]$ & $8[6.0]$ & \multirow[t]{2}{*}{0.943} \\
\hline & Hospitalize n [\%] & $67[50.4]$ & $47[35.3]$ & \\
\hline
\end{tabular}

Data are number [\%] or a median, unless otherwise indicated. *The median values [25p-75p] were indicated because parameters did not fit the normal distribution. WBC: White Blood Cell; CRP: C-Reaktive Protein; NLR: Neutrophil-Lymphocyte ratio; PLR: Platelet-Lymphocyte Ratio; PCR: Polymerase Chain Reaction; CT: Computed Tomography. 
TABLE 5. COMPARISON OF LABORATORY PARAMETERS BETWEEN THE GROUPS.

\begin{tabular}{|c|c|c|c|c|c|}
\hline $\begin{array}{l}\text { Groups } \\
\mathrm{n}[\%]\end{array}$ & $\begin{array}{l}\text { Group } 1 \\
\text { [min-max] }\end{array}$ & $\begin{array}{l}\text { Group } 2 \\
\text { [min-max] }\end{array}$ & $\begin{array}{l}\text { Group } 3 \\
\text { [min-max] }\end{array}$ & $\begin{array}{l}\text { Group } 4 \\
\text { [min-max] }\end{array}$ & $P$ \\
\hline WBC $[K / u L]$ & $7.35[6.17-9.17]$ & $7.29[5.45-9.1]$ & $7.50[5.5-8.45]$ & $5.0[4.4-6.7]$ & 0.000 \\
\hline Neutrophil [K/uL] & $4.70[3.85-6.43]$ & $5.07[2.95-6.50]$ & $4.70[2.85-5.60]$ & $3.30[2.80-4.20]$ & 0.004 \\
\hline Platelets [K/uL] & 206.0 [190.0-266.5] & 193.0 [158.0-266.5] & 208.0 [195.0-260.5] & 166.0 [144.0-212.0] & 0.022 \\
\hline Lymphocytes [K/uL] & $2.05[1.45-2.57]$ & $1.50[1.10-2.10]$ & $2.0[1.15-2.65]$ & $1.3[1.01-1.80]$ & 0.023 \\
\hline CRP $[\mathrm{mg} / \mathrm{L}]$ & 6.5 [2.0-29.75] & $19.0[8.0-71.5]$ & $5.0[1.0-18.5]$ & $18.0[6.0-49.0]$ & 0.001 \\
\hline NLR & $2.42[1.53-4.32]$ & $2.58[1.96-4.84]$ & $2.16[1.31-3.34]$ & $2.50[1.69-3.46]$ & 0.613 \\
\hline PLR & $100.5[82.50-134.1]$ & 130.9 [85.9-205.7] & $124.6[74.3-192.8]$ & 120.6 [80.0-155.6] & 0.430 \\
\hline
\end{tabular}

Data are number [\%] or a median, unless otherwise indicated. ${ }^{*}$ The median values [25p-75p] were indicated because parameters did not fit the normal distribution WBC: White Blood Cell; CRP: C-Reaktive Protein; NLR: Neutrophil-Lymphocyte ratio; PLR: Platelet-Lymphocyte Ratio.

\section{DISCUSSION}

COVID-19 is a pandemic that puts a serious burden on the health system. Therefore, the detection of particularly serious patients at an early stage is extremely important in terms of controlling the outbreak and improving prognosis ${ }^{10}$. COVID-19 can affect all age groups. However, it is believed that the group that is mostly affected is middle-aged and older adults, and that the clinical presentation is more severe in the elderly ${ }^{5}$. Looking at the literature on this issue, the average age of the affected individuals reported was 58 years in a Chinese-based publication, and 65.5 in a US-based study ${ }^{11,12}$. In our study, the average age was 49.5 years. This may be because the population of our country is younger than the population of China and the USA.

COVID-19 infection can affect both women and men. However, its incidence and severity in men are higher than in women. This was the same with MERS-COV and SARS-COV infections, which are of the same family. When the publications on exposure rate of males are examined, it is seen that this rate is $66 \%, 68 \%$, and $75 \%{ }^{12-14}$ for MERS-COV and SARSCOV, respectively. It is believed that this is due to the $\mathrm{X}$ chromosome and sex hormones that exist in females, which play an important role in women's natural and adaptive immunity ${ }^{15}$. Indeed, our results support this data and the proportion of men in our study was $58.6 \%$.

Laboratory markers for COVID-19 are not specific and their clinical benefit is limited. Doctors cannot rely on these laboratory markers to rule out or confirm the diagnosis while evaluating suspected cases. The most frequently reported laboratory abnormalities in the literature are lymphocytopenia and an increase in CRP values ${ }^{14,16}$. Indeed, these laboratory abnormalities were also observed in SARS and MERS patients ${ }^{17-19}$. In our study, only an increase in CRP levels was detected from laboratory results, and this result supports the idea that laboratory markers are not specific for COVID-19. However, a different situation emerges when results are interpreted considering age and gender. In our results, which are compatible with the literature, lymphocytopenia is seen in patients over the age of 50 . On the other hand, when a comparison was made in terms of gender, it was observed that PLT, CRP, and NLR levels increased significantly in men. All these results suggest that age and gender should be taken into consideration when evaluating laboratory results.

A definitive diagnosis of COVID-19 is made by detecting SARS-CoV-2 RNA by RT-PCR ${ }^{20}$. However, the accuracy and predictivity of SARS-CoV-2 tests have not been systematically evaluated. The sensitivity of tests also depends on a precise RT-PCR assay, the type of specimen obtained, the quality of the specimen, and the duration of the illness at the time of testing ${ }^{21}$. In two different studies evaluating PCR, positivity rates were reported as $35 \%$ and $59 \%$. In our study, we found $39.1 \%$ of RT-PCR test positivity.

Compared to PCR, CT imaging may be a more reliable, practical, and fast method to diagnose and evaluate COVID-19, especially in epidemic regions, but availability, radiation, and cost cannot be ignored. In the literature, it is seen that nearly all COVID-19 patients have different ground-glass opacities, reticular interlobular septal thickening, multifocal pneumonia, and architectural distortion in a peripheral distribution ${ }^{6}$. Considering studies on CT positivity, in a meta-analysis of 2738 cases, the rate of COVID-19 compatible cases was $89.76 \%$, while in another study involving 1014 patients, this rate was $88 \%{ }^{6,22}$. In our 
study, the rate of CT-positive patients was found to be $66,2 \%$, similar to the literature. The reason for this may be that the number of patients in our study was less than other studies, and there were not enough PCR kits in our hospital at the beginning. Available data suggest that CT imaging plays a critical role in the initial diagnosis.

For COVID-19 infection, no specific consensus has been reached regarding patient hospitalization or discharge. Studies show that approximately $14 \%$ of those infected with COVID-19 have a serious illness, and 6\% of them are critically ill, so $20 \%$ of all cases need to be hospitalized ${ }^{13}$. In our study, $85,7 \%$ of patients with suspected COVID-19 who attended the emergency service were hospitalized. COVID-19 guidelines were published by The Republic of Turkey Public Health Instutition $^{23}$. In them, hospitalization is recommended for patients over the age of 50 and all age groups with positive CT findings. As a result, our hospitalization rate is high. Once COVID-19 is diagnosed, patients should be isolated from the community, so hospitalization may be increased to provide isolation.

In the absence of specific therapeutic drugs or vaccines for COVID-19, it is essential to detect the disease at an early stage, and immediately isolate the infected person from the healthy population ${ }^{24}$. Therefore, due to the low specificity of laboratory parameters and low positivity rates of RT-PCR tests, CT is needed regardless of the radiation load they create on patients. Indeed, in previous studies supporting this result, the relationship between CT and disease severity has been demonstrated ${ }^{25}$. Considering the comparison between groups in our study, it was revealed that CT was the diagnostic tool that contributed the most to diagnostic processes. In this study, the fact that inflammatory laboratory parameters, especially WBC, NEU, PLT, and LYM showed a significant correlation with the positivity of CT and PCR supports the idea that these should be used together.

\section{CONCLUSIONS}

Laboratory results are not specific enough in the pre-diagnosis. In addition, this result does not alter with PCR or CT positivity. However, minimal changes observed in laboratory results may be partially guiding in patients in whom both PCR and CT are positive.

All authors contributed equally to this study.

The authors declare that they have no conflict of interest. No financial support was received.

\section{RESUMO}

OBJETIVOS: A nova doença de coronavírus de 2019 coloca um fardo sério para o sistema de saúde. Portanto, a detecção de pacientes especialmente graves em um estágio inicial é extremamente importante em termos de controle do surto e melhoria do prognóstico. Investigamos o papel dos marcadores inflamatórios estudados em pacientes suspeitos de COVID-19 no pronto-socorro na previsão de resultados de PCR e CT.

MÉTODOS: Este estudo retrospectivo foi realizado entre 133 pacientes que foram admitidos entre 13 de março e $1^{\circ}$ de abril de 2020 com suspeita de COVID-19. Os pacientes foram divididos em quatro grupos de acordo com os resultados da TC e RT-PCR e avaliados.

RESULTADOS: Considerando todos os pacientes, não foram encontrados achados específicos nos valores hematológicos e bioquímicos dos pacientes em análises laboratoriais. Embora todos os resultados tenham permanecido dentro do intervalo de referência, houve uma diferença significativa nos valores de glóbulos brancos, neutrófilos, plaquetas e linfócitos quando os grupos foram comparados $[p$ $=0,000 ; p=0,004 ; p=0,022 ; p=0,023]$.

CONCLUSÃo: O laboratório não é suficientemente específico no pré-diagnóstico. Além disso, este resultado não se altera com a positividade para PCR ou CT. No entanto, alterações mínimas observadas nos resultados laboratoriais podem ser parcialmente norteadoras em pacientes com $P C R$ e CT positivos.

PALAVRAS-CHAVE: Infecções por Coronavirus/diagnóstico. Testes Laboratoriais. Diagnóstico por Imagem. Tomografia Computadorizada por Raios X. Serviço Hospitalar de Emergência. 


\section{REFERENCES}

1. Zhu N, Zhang D, Wang W, Li X, Yang B, Song J, et al; China Novel Coronavirus Investigating and Research Team. A novel coronavirus from patients with pneumonia in China, 2019. N Engl J Med. 2020;382(8):727-33.

2. World Health Organization. Coronavirus disease (COVID-2019) situation reports [Internet]. Situation report - 91. Geneva: World Health Organization; 2020. [cited 2020 April 20]. Available from: https://www.who.int/ emergencies/diseases/novel-coronavirus-2019/situation-reports

3. Guan W-J, Ni Z-Y, Hu Y, Liang W-H, Ou C-Q, He J-X, et al. Clinical characteristics of coronavirus disease 2019 in China. N Engl | Med. 2020;382(18):1708-20.

4. Rodriguez-Morales AJ, Cardona-Ospina JA, Gutiérrez-Ocampo E, Villamizar-Peña R, Holguin-Rivera Y, Escalera-Antezana JP, et al; Latin American Network of Coronavirus Disease 2019-COVID-19 Research (LANCOVID-19). Electronic address: https://www.lancovid.org. Clinical, laboratory and Imaging features of COVID-19: a systematic review and meta-analysis. Travel Med Infect Dis. 2020;34:101623.

5. Sah R, Rodriguez-Morales AJ, Jha R, Chu DKW, Gu H, Peiris M, et al. Complete genome sequence of a 2019 novel coronavirus (SARS-CoV-2) strain Isolated in Nepal. Microbiol Resour Announc. 2020;9(11):e00169-20.

6. Ai T, Yang Z, Hou H, Zhan C, Chen C, Lv W, et al. Correlation of chest CT and RT-PCR testing in coronavirus disease 2019 (COVID-19) in China: a report of 1014 cases. Radiology. 2020;200642.

7. Adhikari SP, Meng S, Wu YJ, Mao YP, Ye RX, Wang QZ, et al. Epidemiology, causes, clinical manifestation and diagnosis, prevention and control of coronavirus disease (COVID-19) during the early outbreak period: a scoping review. Infect Dis Poverty. 2020;9(1):29. doi: 10.1186/s40249-020-00646-x.

8. Singhal T. A review of coronavirus disease-2019 (COVID-19). Indian | Pediatr. 2020;87(4):281-6.

9. Zhang G, Zhang J, Wang B, Zhu X, Wang Q, Qiu S. Analysis of clinical characteristics and laboratory findings of 95 cases of 2019 novel coronavirus pneumonia in Wuhan, China: a retrospective analysis. Respir Res. 2020;21(1):74.

10. COVID-19 Guide to Public Health in Turkey [Internet]. [cited 2020 April 14]. Available from: https://COVID-19bilgi.saglik.gov.tr/depo/rehberler/ COVID-19_Rehberi.pdf

11. Li G, Clercq ED. Therapeutic options for the 2019 novel coronavirus (2019nCoV). Nat Rev Drug Discov. 2020;19(3):149-50.

12. Wu Z, McGoogan JM. Characteristics of and Important lessons from the coronavirus disease 2019 (COVID-19) outbreak in China: summary of a report of 72314 cases from the Chinese Center for Disease Control and Prevention. JAMA. 2020. doi: 10.1001/jama.2020.2648.
13. Aggarwal S, Garcia-Telles N, Aggarwal G, Lavie C, Lippi G, Henry BM. Clinical features, laboratory characteristics, and outcomes of patients hospitalized with coronavirus disease 2019 (COVID-19): early report from the United States. Diagnosis (Berl). 2020;7(2):91-6.

14. Nikpouraghdam M, Jalali Farahani A, Alishiri G, Heydari S, Ebrahimnia $M$, Samadinia $H$, et al. Epidemiological characteristics of coronavirus disease 2019 (COVID-19) patients in Iran: a single center study. J Clin Virol. 2020;127:104378.

15. Chen N, Zhou M, Dong X, Qu J, Gong F, Han Y, et al. Epidemiological and clinical characteristics of 99 cases of 2019 novel coronavirus pneumonia in Wuhan, China: a descriptive study. Lancet. 2020;395(10223):507-13.

16. Jaillon $S$, Berthenet $K$, Garlanda C. Sexual dimorphism in innate immunity. Clin Rev Allergy Immunol. 2019;56(3):308-21.

17. Liu Y, Yang Y, Zhang C, Huang F, Wang F, Yuan J, et al. Clinical and biochemical Indexes from 2019-nCoV infected patients linked to viral loads and lung Injury. Sci China Life Sci. 2020;63(3):364-74.

18. Leung WK, To KF, Chan PKS, Chan HLY, Wu AKL, Lee N, et al. Enteric involvement of severe acute respiratory syndrome-associated coronavirus Infection. Gastroenterology. 2003;125(4):1011-7.

19. Peiris JSM, Chu CM, Cheng VCC, Chan KS, Hung IFN, Poon LLM, et al. Clinical progression and viral load in a community outbreak of coronavirus-associated SARS pneumonia: a prospective study. Lancet. 2003;361(9371):1767-72.

20. Assiri A, McGeer A, Perl TM, Price CS, Al Rabeeah AA, Cummings DAT, et al; KSA MERS-CoV Investigation Team. Hospital outbreak of middle east respiratory syndrome coronavirus. N Engl | Med. 2013;369(5):407-16.

21. Patel A, Jernigan DB, 2019-nCoV CDC Response Team. Initial public health response and Interim clinical guidance for the 2019 novel coronavirus outbreak - United States, December 31, 2019-February 4, 2020. MMWR Morb Mortal Wkly Rep. 2020;69(5):140-6.

22. Pan $Y$, Guan H, Zhou S, Wang Y, Li Q, Zhu T, et al. Initial CT findings and temporal changes in patients with the novel coronavirus pneumonia (2019-Ncov): a study of 63 patients in Wuhan, China. Eur Radiol. 2020;30(6):3306-9.

23. Bao C, Liu X, Zhang H, Li Y, Liu J. Coronavirus disease 2019 (COVID-19) CT findings: a systematic review and meta-analysis. J Am Coll Radiol. 2020;17(6):701-9.

24. Sjödin H, Wilder-Smith A, Osman S, Faroog Z, Rocklöv |. Only strict quarantine measures can curb the coronavirus disease (COVID-19) outbreak in Italy, 2020. Euro Surveill. 2020;25(13):2000280.

25. Liu KC, Xu P, Lv WF, Qiu XH, Yao JL, Gu JF, et al. CT manifestations of coronavirus disease-2019: a retrospective analysis of 73 cases by disease severity. Eur J Radiol. 2020;126:108941. 